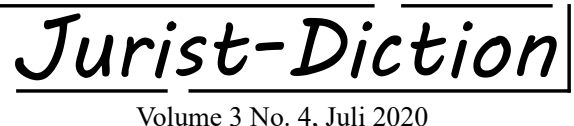

\section{Kedudukan dan Perlindungan Hak Atas Privasi di Indonesia}

\author{
Anjas Putra Pramudito \\ anjasputrap16@gmail.com \\ Universitas Airlangga
}

\begin{abstract}
How to cite:
Anjas Putra Pramudito,

'Kedudukan Dan Perlindungan Hak Atas Privasi di Indonesia' (2020) Vol. 3 No. 4 Jurist-

Diction.

Histori artikel:

Submit 15 Mei 2020; Diterima 16 Juni 2020; Diterbitkan 1 Juli 2020.

DOI:

10.20473/jd.v3i4.20212
\end{abstract}

\begin{abstract}
Abstrak
Artikel ini bertujuan untuk menganalisa pengaturan mengenai hak atas privasi di yang ada di Indonesia. di dalam Analisa ini akan dibagi menjadi dua bagian yaitu mengenai kedudukan dan yang kedua mengenai perlindungan terhadap hak atas privasi yang telah ada di Indonesia. Penentuan kedudukan dari ha katas privasi di Indonesia ini nantinya akan mempengaruhi pengakuan terhadap hak tersebut sebagai bagian dari hak asasi manusia yang diakui di Indonesia. Pengakuan ini juga yang nantinya menentukan ada atau tidaknya perlindungan terhadap hak atas privasi. Dalam penelitian ini menggunakan tipe reform-oriented research dan menggunakan pendekatan perundang-undangan untuk menganalisa ketentuan terkait hak asasi manusia Pendekatan kedua yang digunakan dalam penelitian ini adalah pendekatan konseptual untuk mengetahui konsep dari hak asasi manusia dan privasi. Berdasarkan hasil penelitian ini, ditemukan bahwa hingga saat ini, kedudukan ha katas privasi belum diatur secara eksplisit di dalam konstitusi UUD NRI Tahun 1945. Tetapi, sudah terdapat beberapa peraturan perundang-undangan yang mencantumkan ha katas privasi secara eksplisit seperti contohnya di dalam Undang-Undang Informasi Transaksi Elektronik. Selain itu di beberapa peraturan perundang-undangan lainnya juga telah memiliki ketentuan yang memiliki perlindungan terhadap hak atas privasi individu di Indonesia. Oleh karena itu, dalam hal memberikan perlindungan terhadap ha katas privasi yang lebih pasti dan dijamin secara konsitutisional oleh UUD NRI Tahun 1945, negara harus mempertegas kedudukan hak atas privasi dengan cara mengatur secara eksplisit hak atas privasi di dalam ketentuan UUD NRI Tahun 1945.
\end{abstract}

Kata Kunci: Hak Asasi Manusia; Hak Konstitusional; Hak Atas Privasi.

\section{Pendahuluan}

Globalisasi memberikan dampak yang cukup besar terhadap kehidupan manusia di saat ini. Globalisasi adalah suatu fenomena khusus dalam peradaban manusia yang bergerak terus dalam masyarakat global dan merupakan bagian dari proses manusia global itu. Dengan adanya globalisasi batasan berupa jarak dan waktu antar wilayah yang terpisah sangat jauh sudah dapat lebih 
mudah untuk diakses. Perkembangan globalisasi semakin dipercepat dengan pemanfaatan Ilmu Pengetahuan dan Teknologi atau IPTEK. ${ }^{1}$ Kehadiran teknologi informasi dan teknologi komunikasi mempercepat akselerasi proses globalisasi ini. Salah satu bentuk pemanfaatan IPTEK tersebut yang semakin berkembang pesat saat ini adalah internet. Melalui internet terjadi perubahan situasi sosial di masyarakat seiring dengan jumlah penggunaan internet oleh masyarakat yang cukup tinggi. Berdasarkan polling yang diadakan oleh APJII saja, ditemukan fakta bahwa lebih dari separuh populasi di Indonesia sudah menggunakan internet sebagai salah satu bentuk pemanfaatan ilmu pengetahuan dan teknologi oleh penduduk Indonesia. ${ }^{2}$

Penggunaan internet pada dasarnya merupakan salah satu bentuk dari pemanfaatan ilmu pengetahuan dan teknologi sebagaimana disebut dalam pasal di atas. $^{3}$ Tetapi di sisi lain, pemanfaatan ilmu pengetahuan dan teknologi melalui internet ini juga menimbulkan potensi dilanggarnya Hak Asasi Manusia lainnya yang juga patut dilindungi.

Dari beberapa Hak Asasi Manusia yang ada, salah satu Hak Asasi Manusia yang berpotensi untuk terganggu adalah hak atas privasi (rights to privacy). Gangguan ini disebabkan oleh pemanfaatan ilmu pengetahuan dan teknologi melalui internet yang semakin beraneka ragam. Pemanfaatan ilmu pengetahuan dan teknologi kadang kala disertai dengan keharusan bagi individu untuk menyetorkan data mereka yang bersifat pribadi. Informasi yang terdapat di dalam data ini sifatnya merupakan suatu privasi yang harus dilindungi kerahasiaannya. Hal ini sejalan dengan prinsip mengenai privasi itu sendiri yaitu: "right against disclosure of concealed information; right to limit access to the self; dan/atau control

\footnotetext{
${ }^{1}$ Nurhaidah et al, 'Dampak Pengaruh Globalisasi bagi Kehidupan Bangsa Indonesia' (2015) 3 Jurnal Pesona Dasar.[4].

2 Yudha Pratomo, 'APJII: Jumlah Pengguna Internet di Indonesia Tembus 171 Juta Jiwa' (Kompas Tekno, 2019) <https://tekno.kompas.com/read/2019/05/16/03260037/apjii-jumlah-pengguna-internet-di-indonesia-tembus-171-juta-jiwa> dikunjungi pada tanggal 15 Januari 2020.

3 Nurhaidah, Op.Cit.[5].
} 
of information pertaining to one's self. ${ }^{4}$ mengacu pada prinsip tersebut, maka untuk menghargai privasi seseorang salah satu nya adalah dengan memberikan kesempatan individu tersebut untuk menentukan sendiri informasi apa yang ingin dia sebarkan atau tidak. Kesempatan ini lah yang berpotensi terlanggar dengan adanya pemanfaatan teknologi sebagaimana diamanatkan Pasal 28C UUD NRI Tahun 1945 yang menyatakan:

"Setiap orang berhak mengembangkan diri melalui pemenuhan kebutuhan dasarnya, berhak mendapat pendidikan dan memperoleh manfaat dari ilmu pengetahuan dan teknologi, seni dan budaya, demi meningkatkan kualitas hidupnya dan demi kesejahteraan umat manusia".

Di Indonesia, Hak Asasi Manusia dijamin baik di dalam konstitusinya maupun dalam peraturan perundang-undangan di bawahnya. Penjaminan ini sesuai dengan bentuk negara Indonesia yang merupakan negara hukum sesuai dengan yang telah diamanahkan UUD NRI Tahun 1945. Tindakan penjaminan terhadap Hak Asasi Manusia merupakan salah satu ciri dari negara hukum yaitu memberi pengakuan dan perlindungan Hak Asasi Manusia disertai dengan dibentuknya UUD NRI Tahun 1945 yang bertindak sebagai penjamin konstitusional Hak Asasi Manusia tersebut. ${ }^{5}$

Hak Asasi Manusia adalah hak-hak yang secara inheren melekat dalam diri tiap manusia. Hak Asasi Manusia didasarkan pada prinsip fundamental bahwa semua manusia memiliki martabat yang inheren tanpa memandang jenis kelamin, ras, warna kulit, bahasa, asal usul bangsa, umur, kelas, keyakinan politik dan agama. $^{6}$ Hak Asasi Manusia ini juga bisa menjadi sekumpulan hak yang memiliki sifat normatif atau disebut juga dengan legal rights. Dimana sifat normatif dari Hak Asasi Manusia ini ditandai dengan adanya suatu landasan hukum. ${ }^{7}$ Selain bersifat normatif, Hak Asasi Manusia juga melekat pada setiap orang sebagai bentuk reaksi dari berbagai tindakan yang mengancam kehidupan manusia. Eksistensi Hak Asasi

\footnotetext{
${ }^{4}$ Nadezhda Purtova, 'Private Law Solution in European Data Protection Relationship to Privacy, and Waiver of Data Protection Rights' (2010) 28 Netherlands Quarterly of Human Rights.[3].

5 Ni'matul Huda, Ilmu Negara, (Rajawali Pers 2011).[94].

6 Abul A'la al-Maududi, 'Human Right, The West and Islam', Human Right in Islamic Law, ([s.n] 1993).[2]. 2005).[23].

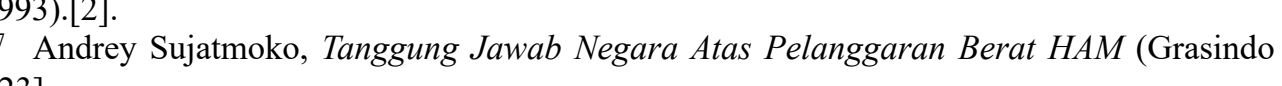


Manusia itu sendiri sudah ada sejak awal manusia berada di bumi dan telah diakui sendiri secara universal. ${ }^{8}$

Dari berbagai macam Hak Asasi Manusia yang ada, terdapat hak dasar yang menjadi landasan adanya hak asasi manusia itu sendiri, yaitu hak atas privasi. Pernyataan ini sejalan dengan konsep hak asasi manusia itu sendiri yang dibangun di atas privasi sebagai dasarnya. ${ }^{9}$ Maka dari itu, dapat dikatakan bahwa hak atas privasi merupakan hak yang cukup fundamental dan sudah seharusnya dimiliki oleh tiap-tiap individu. Dan oleh karena itu diperlukan pengaturan yang baik guna melindungi hak atas privasi guna menjamin hak tersebut tetap terpenuhi dan tidak terganggu karena tindakan tertentu.

Merujuk pada penjabaran di atas, maka sudah sewajarnya setiap orang berhak mendapatkan perlindungan dari segala gangguan atau upaya untuk menembus dan menyalahgunakan segala hal yang termasuk ke dalam ranah privasi mereka. Dalam hal ini perlindungan tersebut dapat diperoleh oleh tiap individu dari pemerintah yang bertanggung jawab untuk memberikan perlindungan tersebut. Berkaitan dengan tanggung jawab negara, istilah tersebut dapat diartikan sebagai suatu kewajiban untuk memberikan jawaban atas perhitungan suatu hal dan kewajiban untuk memberikan pemulihan atas kerugian yang mungkin ditimbulkan. ${ }^{10}$ Oleh karena itu, pada penelitian ini akan mengkaji kedudukan dari hak atas privasi di Indonesia. Penentuan kedudukan dari hak atas privasi ini nantinya yang akan mempengaruhi pengakuan hak atas privasi ini sebagai bagian dari hak asasi manusia di Indonesia. Dari adanya pengakuan tersebut, maka timbul tanggung jawab pemerintah untuk melakukan perlindungan terhadap hak atas privasi itu sendiri. dari sini maka timbul poin ke dua yang dikaji di dalam penelitian ini yaitu mengenai perlindungan terhadap hak atas privasi yang telah berlaku di Indonesia saat ini. Untuk menyelesaikan penelitian ini, maka penelitian ini menggunakan tipe Reform-

\footnotetext{
8 Majda El-Muhtaj, Hak Asasi Manusia dalam Konstitusi Indonesia, Prenada Media 2017).[6].

9 Privacy International, 'What is Privacy' [s.n][s.a] <https:www.privacyinternational.org/ node/54> dikunjungi 15 Januari 2020

${ }^{10}$ F. Sugeng Istanto, Hukum Internasional (Atma Jaya Yogyakarta 1998).[77].
} 
Oriented Research. Dan di dalamnya menggunakan dua macam pendekatan yaitu pendekatan konseptual untuk meneliti konsep dari hak asasi manusia dan mengenai privasi. Lalu menggunakan pendekatan peraturan perundang-undangan untuk mempelajari ketentuan yang sudah ada di peraturan perundang-undangan mengenai hak asasi manusia dan hak atas privasi termasuk di dalamnya adalah UUD NRI Tahun 1945.

\section{Kedudukan Hak Atas Privasi di Indonesia}

Secara definitif apa yang disebut sebagai hak asasi manusia merujuk kepada Pasal 1 ayat (1) Undang-Undang No 39 Tahun 1999 Tentang Hak Asasi Manusia (yang selanjutnya disebut dengan UU HAM) adalah Seperangkat hak yang melekat pada hakikat manusia sebagai makhluk Tuhan yang Maha Esa dan merupakan anugerah-Nya yang wajib dihormati, dijunjung tinggi, dan dilindungi oleh negara hukum, pemerintahan, dan setiap orang, demi kehormatan serta perlindungan harkat dan martabat manusia. Pendapat lainnya mengenai definisi dari hak itu sendiri disampaikan oleh Mochtar Kusumaatmadja dan B. Arief Sidharta yang mengartikan hak sebagai kebebasan seseorang untuk melakukan atau tidak melakukan sesuatu. Kebebasan tersebut berkenaan dengan hal apa saja serta subjek siapa pun individu tersebut. Walaupun begitu, kebebasan tersebut tetap harus berlandaskan pada hukum dan oleh karena itu dilindungi pula oleh hukum. ${ }^{11}$ Antara hak asasi dan kebebasan asasi merupakan dua hal yang sebenarnya sama saja tetapi bergantung pada perspektifnya saja. Apabila dilihat dari perspektif kebebasan manusia untuk bertindak, maka akan disebut sebagai 'hak untuk' (Right To), sedangkan apabila dilihat dari perspektif perlindungan manusia oleh penguasa (pemerintah atau penguasa lain), disebut kebebasan dalam arti 'bebas dari' (freedom of atau freedom from). ${ }^{12}$

Kaitannya dengan hak atas privasi dalam hal ini dapat dilihat dari penggunaan redaksional "Right to" sebagaimana dijabarkan di atas dengan konsep Right to

${ }^{11}$ Mochtar Kusumaatmadja et al, Pengantar Ilmu Hukum: Suatu pengenalan Pertama Ruang Lingkup Berlakunya Hukum Buku I (Alumni Bandung 2000).[90].

12 Max Boli Sabon, Hak Asasi Manusia (Universitas Atma Jaya 2015).[21]. 
Privacy itu sendiri, Konsep mengenai privasi suatu individu awalnya dimulai atas adanya perdebatan putusan-putusan hakim di Inggris dan di Amerika Serikat. ${ }^{13}$ Pada akhirnya, dua penulis Samuel Warren dan Louis Brandeis, menuliskan konsepsi hukum hak atas privasi. Tulisan dengan judul "The Rights to Privacy" ini pun berhasil memberi konsep mengenai hak atas privasi sebagai sebuah hak hukum atau legal rights. ${ }^{14}$ Di mana legal rights itu sendiri dapat diartikan sebagai suatu hak asasi yang didasarkan pada ketentuan di dalam peraturan perundang-undangan. ${ }^{15}$ Konsepsi ini juga dapat dikaitkan dengan definisi privasi itu sendiri yang disampaikan oleh beberapa ahli lainnya. Arthur Miller misalnya, menitikberatkan konsep privasi pada kemampuan masing-masing individu dalam melakukan kontrol terhadap penyebaran hal-hal terkait dirinya sendiri. ${ }^{16}$ Sejalan dengan yang disampaikan oleh Arthur Miller, Alan Westin juga menitikberatkan pada sejauh apa seseorang dapat menentukan sendiri sejauh apa hal-hal terkait dirinya sendiri dapat disebarkan ke pihak-pihak lain. ${ }^{17}$ Berdasarkan penjabaran di atas dapat dilihat bahwa penggunaan redaksional hak atas privasi sudah sesuai dengan perspektif kebebasan manusia untuk bertindak. Hal ini juga telah sesuai dengan definisi dari privasi itu sendiri yang pada intinya merupakan kemampuan seseorang untuk menentukan tindakan dirinya sendiri.

Pengaturan mengenai hak asasi manusia di Indonesia tercantum pada konstitusi UUD NRI Tahun 1945. Pengaturan mengenai Hak Asasi Manusia terdapat pada Bab XA yang terdiri dari Pasal 28A sampai dengan Pasal 28J. Selain itu juga diatur di dalam Pasal 27, Pasal 29, Pasal 34. Selain pengaturan mengenai Hak Asasi Manusia tersebut diatur secara lebih spesifik lagi di dalam Undang-Undang Nomor 39 Tahun 1999 tentang Hak Asasi Manusia.

Untuk hak atas privasi itu sendiri, hak ini juga telah diakui baik melalui konvensi Internasional maupun di tingkat nasional. Pada tingkat internasional

${ }^{13}$ Wahyudi Djafar, 'Hukum Perlindungan Data Pribadi di Indonesia: Lanskap, Urgensi dan kebutuhan Pembaruan' (2019) ELSAM.

${ }^{14}$ Samuel Warren et al, 'The Right to Privacy', (1890) IV Harvard Law Review.

15 Max Boli Sabon, Op.Cit.[6-7].

16 A. F. Westin, Privacy and Freedom (New York: Atheneum 1967).[7-8].

${ }^{17}$ Arthur R. Miller, The Assault on Privacy: Computers, Data Banks, and Dossiers (University of Michigan Press 1971).[25]. 
ketentuan mengenai hak atas privasi ini diatur di dalam Universal Declaration of Human Rights (yang selanjutnya disebut dengan UDHR) tepatnya pada article 12 yang mengatur bahwa tidak ada suatu individu yang boleh diganggu terhadap urusan pribadinya dan oleh karena itu setiap individu juga berhak atas perlindungan dari segala macam gangguan atau pelanggaran terhadap urusan pribadinya. Konsep hak atas privasi pada artikel ini tercantum pada redaksional "urusan pribadi" tiap individu. Dimana urusan pribadi di sini bisa mencakup salah satunya adalah kemampuan seseorang untuk memutuskan apa yang bisa terjadi terhadap dirinya tanpa adanya campur tangan dari pihak lain.

Pada tingkat nasional, konsep hak atas privasi belum diatur secara eksplisit di dalam Konstitusi Negara Indonesia itu sendiri yaitu UUD NRI Tahun 1945. Ketentuan yang paling mendekati mengenai hak atas privasi di UUD NRI Tahun 1945 dapat ditemukan pada pasal 28G Ayat (1). Pada ketentuan pasal 28G Ayat (1) diatur bahwa setiap orang berhak atas perlindungan diri pribadinya masingmasing serta berhak atas rasa aman dari segala gangguan terhadap diri pribadinya itu sendiri. Konsep hak atas privasi pada ketentuan pasal ini terdapat pada redaksional "diri pribadi" dimana di dalamnya termasuk adalah segala urusan pribadi termasuk penentuan sikap individu tersebut dalam melakukan atau tidak melakukan suatu perbuatan. Konsep ini juga telah tercantum secara jelas di pasal tersebut bahwa setiap orang berhak atas rasa aman dan perlindungan dari ancaman ketakutan untuk berbuat atau tidak berbuat sesuatu yang merupakan hak asasi. Di luar dari itu, konsepsi mengenai hak atas privasi di Indonesia sudah diatur secara eksplisit dalam salah satu peraturan perundang-undangan di Indonesia yaitu pada Undang-Undang Nomor 19 Tahun 2016 jo. Undang-Undang Nomor 11 Tahun 2008 tentang Informasi dan Transaksi Elektronik (yang selanjutnya disebut dengan UU ITE). Selain itu Indonesia juga telah meratifikasi konvensi internasional yang mengandung konsepsi hak atas privasi seperti International Covenant on Civil and Political Rights (yang selanjutnya disebut dengan ICCPR) melalui Undang-Undang Nomor 11 Tahun 2005 tentang Pengesahan International Covenant on Economic, Social and Cultural Rights. 
Di Indonesia sendiri terdapat pembedaan antara hak konstitusional (constitutional rights) dengan hak-hak lain yang tercantum dalam undang-undang (statutory rights). Pada dasarnya di dalam UUD NRI Tahun 1945 tidak diberikan pengertian tentang hak konstitusional. Istilah hak konstitusional baru muncul dan dapat dilihat di dalam UU No. 24 Tahun 2003 tentang Mahkamah Konstitusi yang menyatakan bahwa hak konstitusional adalah hak-hak yang diatur dalam Undang Undang Dasar Negara Republik Indonesia Tahun 1945. ${ }^{18}$ Definisi di dalam UU ini juga sejalan dengan pendapat dari Jimly Asshiddiqie. Menurut Jimly Asshiddiqie, kedua hak tersebut dapat dibedakan antara hak asasi yang diadopsi dalam UUD NRI Tahun 1945 sebagai hak konstitusional sedangkan hak-hak yang diatur secara lebih rinci dan operasional dalam peraturan perundang-undangan sebagai hak lain yang tercantum dalam peraturan perundang-undangan (statutory rights) dan tidak termasuk dalam hak konstitusional. ${ }^{19}$ Kedua hak tersebut merupakan bagian dari legal rights. Selain itu, tidak semua constitutioal rights adalah Hak Asasi Manusia, karena ada juga yang disebut dengan the citizen's constitutional rights, yaitu hak rakyat atau hak warga negara yang hanya berlaku bagi warga negara yang bersangkutan. Akibatnya adalah hak ini tidak berlaku secara universal. Tetapi, pada akhirnya semua human rights adalah the citizen's rights. Perbedaan antara keduanya bukanlah perbedaan substansial melainkan perbedaan lingkungan berlakunya saja. ${ }^{20}$ Pembidangan ini juga berkaitan dengan hak-hak yang digolongkan sebagai hak konstitusional (constitutional rights) yang dibedakan dengan hak-hak yang diatur dalam peraturan perundang-undangan (statutory rights).

Berdasar uraian di atas maka dapat dilihat bahwa terdapat perbedaan antara Right to Privacy dengan Constitutional Right. Right to Privacy dalam hal ini termasuk ke dalam suatu Human Rights. Hal ini berarti bahwa hak tersebut berlaku

\footnotetext{
${ }_{18}$ Pasal 51 ayat (1) jo Penjelasan Pasal 51 ayat (1) UU Nomor 24 Tahun 2003 Tentang Mahkamah Konstitusi (Lembaran Negara 2011 Nomor 70).

19 Jimly Asshiddiqie, 'Hak Konstitusional Perempuan dan Tantangan Penegakannya' Dialog Publik dan Konsultasi Nasional "Perempuan dan Konstitusi di Era Otonomi Daerah: Tantangan dan Penyikapan Bersama” ([s.n] 2007).[1-2].

${ }^{20}$ ibid. [8].
} 
secara universal tanpa batasan ruang dan waktu. Namun dimungkinkan untuk diterapkan dan diadopsi dalam bentuk undang-undang yang berbeda-beda di tiap negara, sedangkan Constitutional Rights di satu sisi merupakan hak-hak yang diatur di dalam konstitusi dari negara yang bersangkutan dan memperoleh perlindungan dari pemerintah atas dasar ada atau tidaknya hak tersebut di dalam konstitusi.

Apabila kita merujuk pada penjelasan di atas maka dapat dilihat bahwa Right to Privacy belum secara tersurat dituliskan di dalam Konstitusi UUD NRI Tahun 1945. Akan tetapi hak tersebut telah diatur dalam salah satu peraturan perundangundangan yaitu pada penjelasan Pasal 26 UU ITE. Di dalam ketentuan penjelasan pasal 26 UU ITE tersebut telah tersurat dengan jelas menyatakan:

Dalam pemanfaatan Teknologi Informasi, perlindungan data pribadi merupakan salah satu bagian dari hak pribadi (privacy rights). Hak pribadi mengandung pengertian sebagai berikut:

a. Hak pribadi merupakan hak untuk menikmati kehidupan pribadi dan bebas dari segala macam gangguan;

b. Hak pribadi merupakan hak untuk dapat berkomunikasi dengan Orang lain tanpa tindakan memata-matai;

c. Hak pribadi merupakan hak untuk mengawasi akses informasi tentang kehidupan pribadi dan data seseorang.

Pada ketentuan di atas, tertulis secara tegas mengenai hak pribadi (Privacy Rights). Walaupun terdapat perbedaan nomenklatur antara Right to Privacy dan privacy rights, pada intinya kedua hak ini memiliki poin yang sama apabila kita lihat pada definisinya di ketentuan pasal tersebut telah menyatakan bahwa yang dimaksud dengan hak pribadi adalah hak untuk menikmati kehidupan pribadi bebas dari segala macam gangguan. Jadi walaupun ada perbedaan nomenklatur, konsep Privacy Rights atau hak pribadi yang tertulis di dalam penjelasan pasal 26 UU ITE sebenarnya memiliki poin yang sama dengan Rights to Privacy. Dengan adanya pengaturan mengenai Privacy Rights di UU ITE tetapi tidak ada penulisan hal yang sama di dalam UUD NRI Tahun 1945, maka bisa dikaitkan dengan pendapat dari Jimly Asshiddiqie bahwa hingga saat ini Right to Privacy belum termasuk ke dalam 
hak konstitusional melainkan hanya merupakan hak yang tercantum di dalam peraturan perundang-undangan lainnya (Statutory Rights) saja.

Walaupun demikian, Mahkamah Konstitusi selaku pihak yang dapat melakukan pengujian undang-undang terhadap UUD NRI Tahun 1945 sesuai dengan wewenangnya pada Pasal 24C ayat (1) UUD NRI Tahun 1945 kerap kali menggunakan batu uji dalam pengujian tidak terbatas pada hak konstitusional saja. Praktik sebagaimana dimaksud dapat dilihat pada putusan MK terkait perkara pengujian undang-undang terhadap UUD NRI Tahun 1945 yang menjadikan 2 (dua) hak yaitu "hak untuk memperoleh bantuan hukum" dan "hak atas praduga tak bersalah" sebagai batu uji dalam perkara tersebut. Melihat pada praktik ini maka dapat dikatakan bahwa yang dapat dikategorikan sebagai Constitutional Rights di Indonesia tidak hanya sebatas pada yang telah tertulis dengan tegas di konstitusi UUD NRI Tahun 1945 saja. Beberapa hak yang tidak termasuk ke dalam Constitutional Rights tetapi diperhitungkan untuk menjadi bahan pertimbangan disebut juga Unnemurated Rights. ${ }^{21}$ sebatas pada yang telah tertulis dengan tegas di konstitusi UUD NRI Tahun 1945 saja. Beberapa hak yang tidak termasuk ke dalam Constitutional Rights tetapi diperhitungkan untuk menjadi bahan pertimbangan disebut juga Unnemurated Rights. ${ }^{22}$

Secara teoritis, norma hak konstitusional diklasifikasikan dalam dua kelompok, yang pertama adalah norma yang tertera jelas dalam teks konstitusi, dan yang kedua adalah norma hak konstitusional turunan (derivative norms). Selain itu, terdapat juga yang dinamakan dengan hak tersirat atau yang disebut dengan Unenumerated Rights. Pada praktik di negara-negara common law, terdapat konsep yang dikenal dengan hak tersirat (Implied Rights atau Unenumerated Rights). Unenumerated Rights adalah hak-hak yang diangkat statusnya sebagai hak konstitusional, meskipun tidak dicantumkan secara eksplisit di dalam konstitusi. ${ }^{23}$

${ }^{21}$ Bisariyadi, 'Menyibak Hak Konstitusional Yang Tersembunyi' (2017) 24 Jurnal Hukum IUS QUIA IUSTUM.[511].

${ }^{22} \mathrm{ibid}$.

23 ibid.[523]. 
Pengangkatan yang dimaksud di atas dapat dilakukan melalui proses penafsiran di lembaga peradilan dalam hal ini melalui MK. Sama halnya dengan "hak untuk memperoleh bantuan hukum" dan "hak atas praduga tak bersalah", "hak atas privasi" juga telah tercantum secara eksplisit di undang-undang yang ada di Indonesia yaitu di dalam UU ITE sebagaimana telah dijelaskan sebelumnya. Tetapi MK perlu menambah ketegasan tentang status hak atas privasi ini agar dapat dikategorikan sebagai Constitutional Rights. Sampai saat ini MK belum memberikan putusan yang secara eksplisit menyatakan hak atas privasi sebagai constitutional Rights sehingga dapat dijadikan batu uji dalam Judicial Review yang dilakukan oleh MK. Hingga saat ini MK hanya menerjemahkan unsur Privacy yang diatur di dalam UDHR dan ICCPR melalui Putusan MK Nomor 50/PUU-VI/2008 tentang Perkara Pengujian Undang-Undang Nomor 11 Tahun 2008 tentang Informasi dan Transaksi Elektronik saja.

\section{Perlindungan Hak Atas Privasi di Indonesia}

Apabila kita merujuk kepada definisi Hak Asasi Manusia sesuai Pasal 1 ayat (1) UU HAM, definisi tersebut tidak hanya memberikan pengertian terhadap apa yang dimaksud dengan Hak Asasi Manusia melainkan menghasilkan pula kewajiban asasi. Kewajiban asasi merupakan kewajiban negara hukum, pemerintah, dan setiap orang untuk menghormati, menjunjung tinggi, dan melindungi hak asasi orang lain. ${ }^{24}$ Kewajiban ini juga melahirkan kewajiban dasar setiap manusia. Merujuk pada Pasal 1 ayat (2) undang-undang yang sama, yang diartikan sebagai suatu kewajiban dasar adalah kewajiban yang apabila tidak dilaksanakan tidak memungkinkan terlaksana dan tegaknya Hak Asasi Manusia itu sendiri. Di seluruh dunia, konsep perlindungan Hak Asasi Manusia dibedakan menjadi 2 (dua) konsep yang berbeda. Menurut konsep dalam sistem hukum Eropa Kontinental (Civil Law System), Perlindungan terhadap Hak Asasi Manusia dilakukan sepanjang HakAsasi Manusia tersebut terdapat di dalam konstitusi negara yang berkaitan. Apabila tidak, maka Hak Asasi Manusia tersebut

\footnotetext{
${ }^{24}$ Pasal 2 Undang-Undang Nomor 39 Tahun 1999 tentang Hak Asasi Manusia (Lembaran Negara Republik Indonesia Tahun 1999 Nomor 65).
} 
tidak mendapat perlindungan dari negara yang bersangkutan. Sementara menurut konsep sistem hukum Anglo Saxon (Common Law System), perlindungan Hak Asasi Manusia tidak bergantung pada konstitusi. Konstitusi harus diubah apabila ada Hak Asasi Manusia yang belum tertuang di dalam konstitusi negara yang bersangkutan agar Hak Asasi Manusia tersebut dapat memperoleh perlindungan. Pandangan ini ada karena konstitusi bukan sumber bagi suatu Hak Asasi Manusia, melainkan konsekuensi dari adanya pengakuan terhadap Hak Asasi Manusia. ${ }^{25}$

Kewajiban untuk menghormati, melindungi dan memenuhi masing-masing mengandung unsur kewajiban untuk bertindak (obligation to conduct), yaitu negara disyaratkan melakukan langkah-langkah tertentu untuk melaksanakan pemenuhan suatu hak, dan kewajiban untuk berdampak (obligation to result), yaitu mengharuskan negara untuk mencapai sasaran tertentu memenuhi standar substantif yang terukur. ${ }^{26}$ Sebagai pihak yang memangku tanggung jawab, negara dituntut harus melaksanakan dan memenuhi semua kewajiban yang dikenakan kepadanya secara sekaligus dan segera. Jika kewajiban-kewajiban tersebut gagal untuk dilaksanakan maka negara akan dikatakan telah melakukan pelanggaran. ${ }^{27}$

Terdapat dua jenis pelanggaran yang dapat terjadi berkaitan dengan pelaksanaan kewajiban dan tanggung jawab negara, baik karena tindakan maupun pembiaran. Sebagaimana tercantum dalam article 11 Maastricht Guidelines, yaitu:

a. "A violation of economic, social and cultural rights occurs when a State pursues, by action or omission, a policy or practice which deliberately contravenes or ignores obligations of the Covenant, or fails to achieve the required standard of conduct or result. Furthermore, any discrimination on grounds of race, colour, sex, language, religion, political or other opinion, national or social origin, property, birth or other status with the purpose or effect of nullifying or impairing the equal enjoyment or exercise of economic, social and cultural rights constitutes a violation of the Covenant". 28

\footnotetext{
${ }^{25}$ Dr. Max Boli Sabon, Op.Cit.[20].

${ }^{26}$ Andi Akhirah Khairunisah 'Penerapan Prinsip-Prinsip Hak Asasi Manusia Dalam Pembentukan Produk Hukum Oleh Pemerintah Daerah' (2018) 5 Jurnal Manajemen Pemerintahan.[68].

${ }^{27}$ Maidah Purwanti, 'Kewajiban dan Tanggung Jawab Negara dalam Pemenuhan Hak Asasi Manusia' [s.n][s.a] <https://lsc.bphn.go.id/artikel?id=365>, dikunjungi pada tanggal 7 Desember 2019.

${ }_{28}$ Maastricht Guidelines on Violations of Economic, Social and Cultural Rights 1997 (University of Minnesota, 1997) < http://hrlibrary.umn.edu/instree/Maastrichtguidelines_html> dikunjungi pada tanggal 7 Desember 2019.
} 
Dari ketentuan yang terdapat pada article 11 Maastrich Guidelines tersebut, dapat dilihat bahwa negara dalam hal ini pemerintah bisa dinyatakan melakukan Pelanggaran karena negara melakukan tindakan langsung untuk mengintervensi pengaturan hak-hak warga negara yang semestinya dihormati. Kemungkinan yang kedua adalah negara melakukan pelanggaran karena melakukan pembiaran dimana negara tidak melakukan tindakan atau gagal untuk mengambil tindakan lebih lanjut yang diperlukan untuk melaksanakan kewajiban hukum.

Kewajiban hukum pemerintah dalam hal memberikan perlindungan hak asasi manusia dapat dilihat pada ketentuan di UUD NRI Tahun 1945. Secara konstitusional, pemerintah dibebani kewajiban untuk melakukan pemenuhan dan perlindungan terhadap Hak Asasi Manusia tiap warga negaranya melalui Pasal 28 I ayat (4) UUD NRI Tahun 1945. Pasal tersebut menyatakan bahwa perlindungan, pemajuan, penegakan, dan pemenuhan Hak Asasi Manusia adalah tanggung jawab negara, terutama pemerintah. Dan untuk menindaklanjuti kewajiban tersebut, pemerintah harus melakukan perlindungan terhadap hak asasi manusia melalui peraturan perundang-undangan. Bentuk perlindungan terhadap Hak Asasi Manusia harus diatur di dalam peraturan perundang-undangan karena sesuai dengan prinsip negara hukum tetapi juga demokratis yang dianut oleh Indonesia. ${ }^{29}$

Di Indonesia. Pada Bab XA UUD NRI Tahun 1945 telah memuat bagian khusus yang mengatur mengenai perlindungan Hak Asasi Manusia. Namun demikian, beberapa peraturan perundang-undangan juga diterbitkan untuk memuat perlindungan Hak Asasi Manusia di antaranya adalah, UU Nomor 39 Tahun 1999 tentang Hak Asasi Manusia, begitu juga undang-undang yang meratifikasi konvensi internasional berkaitan dengan Hak Asasi Manusia di antaranya adalah:

1. UU Nomor 11 Tahun 2005 tentang Pengesahan International Covenant On Economic, Social And Cultural Rights (Kovenan Internasional tentang HakHak Ekonomi, Sosial Dan Budaya), LNRI Tahun 2005 Nomor 118, TLNRI Nomor 4557;

2. UU Nomor 12 Tahun 2005 tentang Pengesahan International Covenant On Civil And Political Rights (Kovenan Internasional tentang Hak-Hak Sipil

${ }^{29}$ Pasal 28I ayat 5 Undang-Undang Dasar Negara Republik Indonesia Tahun 1945. 
Dan Politik), LNRI Tahun 2005 Nomor 119, TLNRI Nomor 4558;

3. UU Nomor 29 Tahun 1999 tentang Pengesahan International Convention on the Elimination of All Forms of Racial Discrimination 1965 (Konvensi Internasional tentang Penghapusan Segala Bentuk Diskriminasi Rasial 1965);

4. UU Nomor 7 Tahun 1984 tentang Pengesahan Konvensi Mengenai Penghapusan Segala Bentuk Diskiriminasi Terhadap Wanita (Convention On The Elimination Of All Forms Of Discrimination Against Women), LNRI Tahun 1984 Nomor 29, TLNRI Nomor 3227;

5. UU Nomor 6 Tahun 2012 tentang Pengesahan International Convention On The Protection Of The Rights Of All Migrant Workers And Members Of Their Families (Konvensi Internasional Mengenai Perlindungan Hak Hak Seluruh Pekerja Migran Dan Anggota Keluarganya), LNRI Tahun 2012 Nomor 115, TLNRI Nomor 5314;

6. UU Nomor 19 Tahun 2011 tentang Pengesahan Convention On The Rights Of Persons With Disabilities (Konvensi Mengenai Hak-Hak Penyandang Disabilitas), LNRI Tahun 2011 Nomor 107, TLNRI Nomor 5251.

Selain peraturan perundang-undangan yang mengatur ketentuan mengenai hak asasi manusia, perlindungan ha katas privasi yang dilakukan oleh pemerintah juga dituangkan ke dalam peraturan perundang-undangan yang memberi perlindungan terhadap data pribadi di Indonesia. hal ini dikarenakan sifat data pribadi itu sendiri yang bisa digunakan untuk mengidentifikasi seseorang. Identifikasi seseorang disini berkaitan dengan kosnep privasi yang memberikan kesempatan seseorang untuk menjaga kerahasiaan informasi pribadinya. Oleh karena itu, dengan adanya perlindungan data pribadi seseorang di saat yang sama juga telah melindungi hak atas privasi individu tersebut. Di Indonesia sendiri ada beberapa peraturan perundangundangan yang memberikan ketentuan perlindungan terhadap penggunaan data pribadi yaitu:

1. Undang-Undang Nomor 24 Tahun 2013 jo. Undang-Undang Nomor 23 Tahun 2006 tentang Administrasi Kependudukan;

2. Peraturan Pemerintah Nomor 40 Tahun 2019 tentang Pelaksanaan UndangUndang Nomor 23 Tahun 2006 tentang Administrasi Kependudukan;

3. Peraturan Menteri Dalam Negeri Republik Indonesia Nomor 61 Tahun 2015 tentang Persyaratan, Ruang Lingkup, Dan Tata Cara Pemberian Hak Akses Serta Pemanfaatan Nomor Induk Kependudukan, Data Kependudukan dan Kartu Tanda Penduduk Elektronik;

4. Undang-Undang Nomor 19 Tahun 2016 jo. Undang-Undang Nomor 11 Tahun 2008 tentang Informasi dan Transaksi Elektronik;

5. Peraturan Pemerintah Nomor 71 Tahun 2019 Tentang Penyelenggaraan Sistem dan Transaksi Elektronik; 
6. Undang-Undang Nomor 14 Tahun 2008 Tentang Keterbukaan Informasi Publik;

7. Undang-Undang Nomor 36 Tahun 2009 Tentang Kesehatan.

\section{Kesimpulan}

Hak atas Privasi merupakan salah satu hak asasi manusia yang sudah diakui di dunia internasional melalui beberapa konvensi seperti UDHR dan ICCPR. Dimana di Indonesia sendiri hingga saat ini masih belum mengatur secara eksplisit dan secara tegas mengenai hak atas privasi di konstitusi UUD NRI 1945. Pengakuan Indonesia terhadap kedudukan hak atas privasi selaku bagian dari hak asasi manusia masih sebatas pada ratifikasi yang dilakukan Indonesia terhadap konvensi internasional seperti UDHR dan ICCPR. Selain itu, hak atas privasi juga telah diatur secara eksplisit di salah satu peraturan perundang-undangan di bawah UUD NRI Tahun 1945 yaitu di dalam Undang-Undang Informasi \& Transaksi Elektronik.

Walaupun belum diatur secara tegas di konstitusi, Indonesia tetap mengakui adanya hak atas privasi dan memiliki tanggung jawab untuk melakukan perlindungan terhadap hak tersebut. Perlindungan hak atas privasi oleh pemerintah dituangkan di dalam peraturan perundang-undangan yang telah ada dan berlaku di Indonesia hingga saat ini. Terlepas akan hal tersebut, kedudukan hak atas privasi selaku bagian dari hak asasi manusia masih harus dipertegas lagi di dalam konsitusi UUD NRI Tahun 1945. Tindakan mempertegas ini bisa dilakukan oleh pemerintah melalui mekanisme perubahan UUD NRI tahun 1945 itu sendiri yaitu melalui mekanisme amandemen.

\section{Daftar Bacaan}

\section{Buku}

A. F. Westin, Privacy and Freedom (New York: Atheneum 1967).

Andrey Sujatmoko, Tanggung Jawab Negara Atas Pelanggaran Berat HAM (Grasindo 2005).

Arthur R. Miller, The Assault on Privacy: Computers, Data Banks, and Dossiers (University of Michigan Press 1971). 
F. Sugeng Istanto, Hukum Internasional (Atma Jaya Yogyakarta 1998).

Majda El-Muhtaj, Hak Asasi Manusia dalam Konstitusi Indonesia, Prenada Media 2017).

Max Boli Sabon, Hak Asasi Manusia (Universitas Atma Jaya 2015).

Mochtar Kusumaatmadja et al, Pengantar Ilmu Hukum: Suatu pengenalan Pertama Ruang Lingkup Berlakunya Hukum Buku I (Alumni Bandung 2000).

Ni'matul Huda, Ilmu Negara, (Rajawali Pers 2011).

Nurhaidah et al, 'Dampak Pengaruh Globalisasi bagi Kehidupan Bangsa Indonesia' (2015) 3 Jurnal Pesona Dasar.

\section{Jurnal}

Abul A'la al-Maududi, 'Human Right, The West and Islam', Human Right in Islamic Law, ([s.n] 1993).

Andi Akhirah Khairunisah 'Penerapan Prinsip-Prinsip Hak Asasi Manusia Dalam Pembentukan Produk Hukum Oleh Pemerintah Daerah' (2018) 5 Jurnal Manajemen Pemerintahan.

Bisariyadi, 'Menyibak Hak Konstitusional Yang Tersembunyi' (2017) 24 Jurnal Hukum IUS QUIA IUSTUM.

Nadezhda Purtova, 'Private Law Solution in European Data Protection Relationship to Privacy, and Waiver of Data Protection Rights' (2010) 28 Netherlands Quarterly of Human Rights.

Samuel Warren et al, 'The Right to Privacy', (1890) IV Harvard Law Review.

Wahyudi Djafar, 'Hukum Perlindungan Data Pribadi di Indonesia: Lanskap, Urgensi dan kebutuhan Pembaruan' (2019) ELSAM.

\section{Makalah}

Jimly Asshiddiqie, 'Hak Konstitusional Perempuan dan Tantangan Penegakannya' Dialog Publik dan Konsultasi Nasional "Perempuan dan Konstitusi di Era Otonomi Daerah: Tantangan dan Penyikapan Bersama” ([s.n] 2007).

\section{Laman}

Maidah Purwanti, 'Kewajiban dan Tanggung Jawab Negara dalam Pemenuhan Hak 
Asasi Manusia' [s.n][s.a] <https://lsc.bphn.go.id/artikel?id=365>, dikunjungi pada tanggal 7 Desember 2019.

Maastricht Guidelines on Violations of Economic, Social and Cultural Rights 1997 (University of Minnesota, 1997) < http://hrlibrary.umn.edu/instree/ Maastrichtguidelines_html> dikunjungi pada tanggal 7 Desember 2019.

Yudha Pratomo, 'APJII: Jumlah Pengguna Internet di Indonesia Tembus 171 Juta Jiwa' (Kompas Tekno, 2019) <https://tekno.kompas.com/ $\mathrm{read} / 2019 / 05 / 16 / 03260037 /$ apjii-jumlah-pengguna-internet-di-indonesiatembus-171-juta-jiwa $>$ dikunjungi pada tanggal 15 Januari 2020.

Privacy International, 'What is Privacy’ [s.n][s.a] $<$ https:www.privacyinternational. org/node/54> dikunjungi 15 Januari 2020.

\section{Perundang-undangan}

Undang-Undang Dasar Negara Republik Indonesia Tahun 1945.

Undang-Undang Nomor 39 Tahun 1999 tentang Hak Asasi Manusia (Lembaran Negara Republik Indonesia Tahun 1999 Nomor 65).

Penjelasan Undang-Undang Nomor 24 Tahun 2003 Tentang Mahkamah Konstitusi (Lembaran Negara 2011 Nomor 70). 
1414 Anjas Putra: Kedudukan dan Perlindungan

--halaman ini sengaja dibiarkan kosong-- 